\title{
CAPITAL COST QUANTIFICATION MODEL IN BUSINESS ACTIVITY PLANNING: THE EVIDENCE OF THE MIDDLE EUROPE COUNTRIES
}

\author{
Zuzana Rowland ${ }^{1, \mathrm{a}}$, Tomas Krulicky ${ }^{2, \mathrm{~b},{ }^{*}}$ and Olena Oliinyk ${ }^{3, \mathrm{c}}$ \\ ${ }^{1}$ Institute of Technology and Business in Ceske Budejovice, Okruzni 517/10, 37001 \\ Ceske Budejovice, Czech Republic \\ ${ }^{2}$ Institute of Technology and Business in Ceske Budejovice, Okruzni 517/10, 37001 \\ Ceske Budejovice, Czech Republic \\ ${ }^{2}$ National University of Water and Environmental Engineering, Soborna atr. 11, 33028 Rivne, Ukraine \\ a24786@mail.vstecb.cz, ${ }^{\mathrm{b}}$ vrbka@mail.vstecb.cz, ${ }^{\mathrm{c}}$ O.o.oliynuk@nuwm.edu.ua \\ *Corresponding author
}

Cite as: Rowland, Z., Krulicky, T., Oliinyk, O. (2020). Capital cost quantification model in business activity planning: the evidence of the middle Europe countries. Ekonomicko-manazerske spektrum, 14(1), 30-42.

Available .at: dx.doi.org/10.26552/ems.2020.1.30-42

\begin{abstract}
Costs of capital are the most important measure for evaluating financial decisions. Cost of capital is the minimum rate of return that a business must earn before generating value. Before a business can turn a profit, it must at least generate sufficient income to cover the cost of the capital it uses to fund its operations. This consists of both the cost of debt and the cost of equity used for financing a business. Costs of capital determine not only the degree of obstacles for investment projects, but also the composition of the company's capital structure. In addition, the determinants of the cost of capital (in particular the cost of equity) are relevant to the literature on a basic analysis that seeks to clarify the evaluative role of accounting. The aim of the article is to form a model for the calculation of the cost of capital on a sample of 3,583 companies in Central European countries. The model was formed using the principles of the linear regression analysis on the samples of both individual countries and Visegrad group. In linear regression, the relationships are modeled using linear predictor functions whose unknown model parameters are estimated from the data. The results of the realized regression models underline the most significant predictors for each country when estimating the costs of capital, which can help these companies to plan their further business activities.
\end{abstract}

Keywords: cost of capital, regression model, post-Soviet countries, modeling

JEL Classification: D24, D23, G30

\section{Introduction}

The estimation of the cost of capital is one of the basic pillars used to convert the flow of expected income into an estimate of present value. This makes it possible to make informed decisions about the prices of purchases and sales of individual items of both equity and debt. Among other things, we can also compare individual investment opportunities. In valuing and making financial decisions, the cost of capital is as important as estimating the estimated amounts of income that will either be discounted or capitalized (Valaskova et al., 2019). 
As there is currently no model that would be able to calculate the cost of capital of companies exclusively in the conditions of the V4 countries, the main goal of the paper is to construct a variant model in the conditions of the Visegrad Four countries based on Anglo-Saxon capital cost quantification models.

The paper is divided into several sections. The first part is devoted to the analysis and description of various views on the issue of the cost of capital. The methodology contains the characteristics of the variables used, the research methods used and the construction of individual models for the quantification of the cost of capital in the conditions of the Visegrad Four countries, for which the basic metrics of regression analysis were used. The underlying data from 3,583 companies come from the Amadeus financial database, which has been used to construct alternative models for calculating the cost of capital for companies for the V4 countries.

\section{Literature Review}

However, the traditional model of valuing capital assets does not allow for any role of information. Easley and O'Hara (2004) therefore note that: "This exclusion of the information role is particularly striking given the perceived importance of market efficiency in valuing assets. If the information is important for the market, why shouldn't it also matter to the companies that are in it? ". The theory suggests that more information is associated with lower cost of capital through reduced transaction costs and / or reduced estimation risk.

Glosten and Milgrom (1985) suggest a positive role for information in reducing the spread of supply and demand. They note that "the main idea is that the specialist faces an unfavorable selection problem, because a customer who agrees to trade based on the price of the specialist's demand or offer can trade because he knows something that the specialist does not know."

Amihud and Mendelson (1986, p. 224) propose and find evidence that is consistent with the hypothesis that average returns adjusted for portfolio risk increase as their demand and supply spread. They note that "the main idea is that the specialist faces an unfavorable selection problem because a customer who agrees to trade based on the price of the specialist's demand or supply can trade because he knows something the specialist does not know." Authors suggest and find evidence that is consistent with the hypothesis that average returns adjusted for portfolio risk increase as their demand and supply spread. They offer information that "liquidity-enhancing financial policies can reduce the opportunity cost of a company's capital and provide a measure of the value of improvements in the trading and exchange process."

The uncertainty of the parameters (estimation risk) is influenced by the perceived unconditional distribution of returns, on the basis of which investors make their investment decisions. Increasing the information in such a setting allows investors to better estimate the return on assets, which in turn reduces the required rate of return (Clarkson et al. 1996).

The link between the quality of information and the cost of capital is one of the basic principles of financing and accounting (Lambert et al., 2007; Vitolla et al., 2019), however, the latest research shows the impact of CSR activities on costs of capital (Dhaliwal et al., 2011; Bae et al., 2019). Due to the information asymmetry resulting from the dispersion of ownership, unfavorable selection costs arise between buyers and sellers of company shares. This should lead to a reduction in the liquidity level of fixed shares. To overcome the reluctance of potential investors to hold solid stakes in illiquid markets, firms must issue discounted capital. Discounting leads to a lower return on the company, and thus to higher capital costs. The commitment to increase the level of disclosure reduces the possibility of information asymmetry and should therefore lead to lower costs for the capital effect (Mihov and Naranjo, 
2019; Chordia et al., 2019). The company could also reduce its capital costs by structuring its management system in a way that allows for transparency and monitoring of management activities. Quality audits, analyst forecasts, etc. in addition, they could provide reliable market information regarding the future prospects of the firm, and thus could reduce capital costs in general, and capital costs in particular (Wang et al., 2020).

Despite the fact that the cost of equity plays an important role in management decisions, in deciding on the valuation of investors' equity, etc., there is no well-accepted approach to estimating it. Most empirical work on asset valuation relies on average realized returns to replace expected returns. Although asset valuation theories require ex-ante (expected) revenue measures, the extensive use of realized revenues is due in part to the fact that expected returns are not observable. In addition, the use of realized returns is hindered because, in an efficient market where risk is adequately valued, ex post average realized returns should be an unbiased estimate of undetectable expected ex ante returns (Gebhardt et al., 2001).

Fama and French (1997) concluded that estimates of the cost of capital based on average realized returns are necessarily inaccurate. They identify three potential problems with risk premiums calculated from past realized returns, difficulties in identifying the correct asset valuation model, inaccuracies in factor burden estimates, and inaccuracies in risk premium estimates.

Botosan and Plumlee (2005) say that the formula for discounting dividends to measure the cost of equity is interesting as it is promising. The short-term form of the classic dividend discounting model corresponds to the current share price of the final series of expected future cash flows and the final value discounted to the present at the cost of equity. Since most of the expected future cash flows are at final value, the successful deduction of equity costs depends to a large extent on the ability to recognize a forecast of market value in the market. Botosan (1997) calculates the cost of capital based on an accounting formula based on Edwards and Bell (1961), Ohson (1995) and Feltham and Ohson (1995). Based on revenue forecasts and book values in the value line and large forecasts of yields, book values, price / profit (P / E) ratio, maximum price and minimum price, it estimates the average (average) cost of capital. Estimating the cost of equity increases market risk and reduces the size of companies. However, as it focused mainly on documenting the negative relationship between the cost of equity estimates and the level of disclosure, it did not perform any further test on the validity of the cost of equity estimate.

Guay et al. (2011) argue that analysts are slow in reassessing their estimates of future earnings with changes in stock prices. The cost of equity estimates based on analyst forecasts is therefore inaccurate. In line with this hypothesis, they did not find any significant positive relationship between the cost of capital estimates and the annual realized returns. They further document that the estimated cost of equity contains a foreseeable error, which is attributed to slow revisions of their analyst estimates. This error is negatively related to the company's immediate performance in the past, and therefore the cost of capital, based on analysts' forecasts, is negatively related to current stock price developments. They propose to include delayed return on inventories in the regression of annual inventory returns from cost of capital estimates.

In order to control the stagnation in the revisions of analysts' forecasts, the authors propose to give analysts more time to make information available and to remove obsolete forecasts. Lee et al. (2009) use data from the G-7 countries to propose a practical approach to estimating the cost of equity to help with international investment and to perform tests of the international asset valuation model using forward-looking equity measurement measures. Whether the effect of company-specific information characteristics can be considered as an effect that can also be 
applied to the cost of capital requires a balance model with rational agents who fail to diversify information risk (Francis et al. 2004). Easley et al. (2004) developed a model in which differences in public and private information affect the cost of capital, with investors demanding higher returns to hold stocks with more private, less public, information.

Leuz and Verrecchia (2004) have taken a slightly different approach and consider the quality of information to be a very important signal in reconciling companies and investors with regard to capital investment. Poor quality report impairs coordination between firms and their investors in the company's capital investment decisions and therefore creates information risk that leads to higher expected returns. Disclosure of company information is crucial for the functioning of an efficient capital market. The demand for financial disclosures stems from information asymmetries and agency conflicts between managers and external investors (Kent and $\mathrm{Bu}$, 2020).

Botosan (1997) takes the first step in directly measuring the cost of equity based on an accounting-based equity valuation technique and provides direct evidence of a negative and statistically significant relationship between the level of voluntary disclosure and the cost of equity. They found that the cost of equity was negatively related to the disclosure score for a firm with a low analytical result, but not for firms with a high analytical result.

Botosan and Plumlee (2002) extend the idea of Botosan (1997) that greater publication of annual reports is associated with lower costs of capital. They argue that more frequent disclosures could attract transient investors who are aggressively trading short-term income. However, Gietzman and Ireland (2005) find a hypothetically negative relationship between the level of timely disclosure and the cost of equity in the United Kingdom context. They are designing an innovative measure for timely strategic disclosure. Based on this early disclosure measure, they will find that early disclosure is associated with reduced equity costs and the effect is more pronounced for firms that apply aggressive accounting principles.

Kothari et al. (2009) find evidence that favorable resp. unfavorable disclosures reduce resp. they increase the cost of equity, but the impact varies depending on who discloses it. The most significant effect occurs in the case of financial press releases, as these reporters usually do not have strong economic ties and relationships with individual firms and can report separately. On the contrary, the disclosure of information by analysts has no significant effect on the cost of equity, as these analysts suffer from a lack of objectivity because they tend to treat management favorably.

Francis et al. (2005), in an international setting, examines whether the need for external financing of a company leads to voluntary incentives for executive disclosure and whether this in turn leads to a reduction in the cost of capital in countries outside the United States. Francis et al. (2004) examine the relationship between the properties of returns and the cost of capital. They assume that since earnings are the primary source of company-specific information and that information is valued, $i$. affect the cost of equity, there should be an inverse relationship between the attributes of returns and the cost of capital. These results are confirmed by Egli et al. 2019. Francis et al. (2005) offer the view that information risk due to poor company-specific information that is relevant for investment decisions is non-diversifiable. Risk factors indicate that this risk is valued at the cost of capital, which is highlighted in the research of Bernardi et al. (2019), Brealey et al. (2020) and Callen and Lyle (2019).

\section{Data and Methodology}

The aim and essence of the paper is to construct a variant model in the conditions of the V4 countries on the basis of Anglo-Saxon capital cost quantification models. 
Capital cost quantification model in business activity planning:

The evidence of the middle Europe Countries

Authors: Zuzana Rowland, Tomas Krulicky and Olena Oliinyk

\section{Research data}

As a source for background data for the Visegrad Four countries, we used a database of comparable financial information for public and private companies across Europe, Amadeus. The target group is 3,583 joint stock companies across all V4 countries, during 2016, 2017 and 2018. The table that follows (Table 1) describes the total number of monitored companies for each country.

Table 1: Number of monitored enterprises in the respective country

\begin{tabular}{ll}
\hline Country & Number of enterprises \\
\hline Slovak Republic (SR) & 902 \\
Republic of Poland (PL) & 438 \\
Republic of Hungary (HU) & 607 \\
Czech Republic (CZ) & 1.636 \\
Total & 3.583 \\
\hline
\end{tabular}

Source: own processing

For the sake of easier readability and clarity, we characterized the obtained data using descriptive statistics. The following table shows the arithmetic mean, median, standard deviation and coefficient of variation for each data set from each country, averaged over the three reference years.

Table 2: Descriptive country statistics

\begin{tabular}{|c|c|c|c|c|c|}
\hline \multirow[b]{2}{*}{ Country } & \multirow[b]{2}{*}{ Variable } & \multicolumn{4}{|c|}{ Indicator } \\
\hline & & $\begin{array}{c}\text { Arithmetic } \\
\text { mean }\end{array}$ & Median & $\begin{array}{l}\text { Standard } \\
\text { deviation }\end{array}$ & $\begin{array}{c}\text { Coefficient } \\
\text { of variation }\end{array}$ \\
\hline \multirow{11}{*}{ 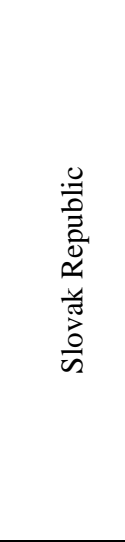 } & Total assets [thous. $€$ ] & $58,300.98$ & $11,371.80$ & $370,838.34$ & 6.36 \\
\hline & Total liabilities [thous. $€$ ] & $58,300.98$ & $11,371.80$ & $370,838.34$ & 6.36 \\
\hline & Long-term liabilities [thous. $€$ ] & $20,864.34$ & $1,448.51$ & $198,212.32$ & 9.49 \\
\hline & Short-term liabilities [thous. $€$ ] & $13,353.47$ & $4,468.68$ & $30,066.76$ & 2.25 \\
\hline & Equity [thous. $€$ ] & $24,083.17$ & $3,728.03$ & $166,094.84$ & 6.91 \\
\hline & Turnover [thous. $€$ ] & $33,411.85$ & $8,613.25$ & $94,167.49$ & 2.82 \\
\hline & Revenues [thous. $€$ ] & $33,248.46$ & $8,457.98$ & $94,142.61$ & 2.83 \\
\hline & EBIT [thous. $€$ ] & $2,510.45$ & 254.19 & $19,523.33$ & 7.76 \\
\hline & EBITDA [thous. $€$ ] & $4,670.39$ & 747.69 & $26,474.05$ & 5.64 \\
\hline & Interest expenses [thous. $€$ ] & 42,742 & 65.16 & $2,551.30$ & 5.96 \\
\hline & Number of employees & 193.87 & 75 & 641.73 & 3.31 \\
\hline \multirow{12}{*}{ 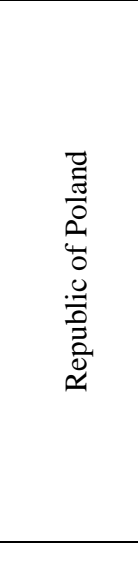 } & Total assets [thous. $€$ ] & $62,511.64$ & $12,373.21$ & $301,421.47$ & 4.82 \\
\hline & Total liabilities [thous. $€$ ] & $62,511.64$ & $12,373.21$ & $301,421.47$ & 4.82 \\
\hline & Long-term liabilities [thous. $€$ ] & $7,890.16$ & $1,238.41$ & $37,035.74$ & 4.69 \\
\hline & Short-term liabilities [thous. $€$ ] & $22,266.78$ & $4,206.85$ & $122,187.29$ & 5.48 \\
\hline & Equity [thous. $€$ ] & $31,521.89$ & $5,002.04$ & $188,249.57$ & 5.97 \\
\hline & Turnover [thous. $€$ ] & $70,776.57$ & $12,231.01$ & $564,097.76$ & 7.97 \\
\hline & Revenues [thous. $€$ ] & $69,988.54$ & $11,748.90$ & $563,326.64$ & 8.04 \\
\hline & EBIT [thous. $€$ ] & $3,649.89$ & 477.42 & $27,394.30$ & 7.50 \\
\hline & EBITDA [thous. $€$ ] & $6,111.32$ & 890.67 & $40,310.61$ & 6.60 \\
\hline & Interest expenses [thous. $€$ ] & 375.19 & 78.25 & $1,868.98$ & 4.96 \\
\hline & Number of employees & 384.59 & 116.67 & $2,980.23$ & 7.74 \\
\hline & Total assets [thous. $€$ ] & $106,423.48$ & $16,338.58$ & $438,052.20$ & 4.11 \\
\hline
\end{tabular}




\begin{tabular}{|c|c|c|c|c|c|}
\hline \multirow{10}{*}{ 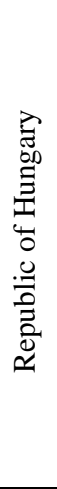 } & Total liabilities [thous. $€$ ] & $106,423.48$ & $16,338.58$ & $438,052.20$ & 4.11 \\
\hline & Long-term liabilities [thous. $€$ ] & $27,252.06$ & $1,089.50$ & $199,228.11$ & 7.26 \\
\hline & Short-term liabilities [thous. $€$ ] & $41,857.39$ & $5,983.83$ & $223,175.44$ & 5.29 \\
\hline & Equity [thous. $€$ ] & $37,314.03$ & $6,769.05$ & $151,107.58$ & 4.05 \\
\hline & Turnover [thous. $€$ ] & $88,317.74$ & $20,337.83$ & $251,260.60$ & 2.85 \\
\hline & Revenues [thous. $€$ ] & $76,551.98$ & $18,585.49$ & $221,078.89$ & 2.89 \\
\hline & EBIT [thous. $€$ ] & $4,524.37$ & 715.29 & $21,900.56$ & 4.81 \\
\hline & EBITDA [thous. $€$ ] & $8,739.23$ & $1,439.71$ & $32,591.69$ & 3.72 \\
\hline & Interest expenses [thous. $€$ ] & 617.81 & 48.88 & $3,004.42$ & 4.89 \\
\hline & Number of employees & 600.53 & 162.83 & $2,639.37$ & 4.40 \\
\hline \multirow{11}{*}{ 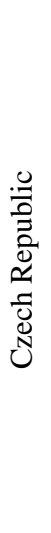 } & Total assets [thous. $€$ ] & $45,508.46$ & $11,155.94$ & $243,022.06$ & 5.35 \\
\hline & Total liabilities [thous. $€$ ] & $45,546.33$ & $11,155.94$ & $243,458.37$ & 5.35 \\
\hline & Long-term liabilities [thous. $€$ ] & $6,457.44$ & $1,154.21$ & $35,130.95$ & 5.40 \\
\hline & Short-term liabilities [thous. $€$ ] & $11,882.39$ & $2,888.66$ & $47,503.39$ & 4.01 \\
\hline & Equity [thous. $€$ ] & $27,206.50$ & $5,391.19$ & $184,198.28$ & 6.78 \\
\hline & Turnover [thous. €] & $39,909.10$ & $9,969.49$ & $170,881.05$ & 4.28 \\
\hline & Revenues [thous. $€$ ] & $36,015.97$ & $8,930.65$ & $150,504.85$ & 4.18 \\
\hline & EBIT [thous. $€$ ] & $1,720.11$ & 379.48 & $11,322.35$ & 6.59 \\
\hline & EBITDA [thous. $€$ ] & $3,235.69$ & 866.94 & $19,223.91$ & 5.94 \\
\hline & Interest expenses [thous. $€$ ] & 226.71 & 48.16 & $1,006.79$ & 4.42 \\
\hline & Number of employees & 209.47 & 76.67 & 498.47 & 2.38 \\
\hline
\end{tabular}

Source: own processing

The statistical file represents a set of joint-stock companies operating on the Slovak, Polish, Hungarian and Czech markets. The statistical unit to be measured will therefore be one of the 3,583 selected joint stock companies, depending on the country operating, which provided their background data to the Amadeus database. The statistical features can then include the cost of capital (dependent variable), as well as all assessed independent variables - capital structure, size, profit before tax, interest, taxes and depreciation, profit before tax and interest, company turnover, company sales and number of employees. As we process data from 3,583 joint-stock companies in a time interval of 3 years, we receive a total of 10,749 values for each variable. We will use these values as input data for the IBM SPSS statistical software. Calculations of values for individual variables can be seen below.

\section{Methodological steps}

When using regression analysis, the relationship between two, resp. several variables. It is assumed that one variable depends on a certain other variable that affects it. The variable that is dependent on one or more variables is called dependent, and in the regression analysis we can find it under the designation Y. On the opposite side of the equation are those variables that can be marked as independent and to some extent affect the observed variable Y. Such variables are marked as $\mathrm{X}$ and can also be characterized as predictors. If there is a linear relationship between the variables, it is possible, based on regression analysis, exactly, mathematically to specify such a relationship by means of a regression equation. The procedure for regression analysis is as follows:

1. Determination of the null hypothesis $\mathrm{HO}$ - the statement of the null hypothesis is that the regression model is not statistically significant. 
2. Determination of the alternative hypothesis $H 1$ - resulting from the formulation of the null hypothesis, he claims that the created regression model is statistically significant, as it negates the original null hypothesis.

3. Determination of the significance level $\alpha$ - this level characterizes the probability that we will reject it even if the null hypothesis is valid. We set it at $10 \%$.

4. Calculation of test statistics - we determine by means of a p-value (probability level), which determines the systematic action or just a coincidence in the difference found between the compared data samples.

5. Decision to accept or reject the null hypothesis - we compare the p-value with the significance level $\alpha$. If the p-value $<\alpha$, the null hypothesis is rejected against the corresponding alternative hypothesis, which implies that the regression model can be considered statistically significant. Otherwise, if the p-value $\geq \alpha$, we do not reject the null hypothesis, which means that the regression model is statistically insignificant.

If we consider the model to be statistically significant, the individual variables in the model are tested for significance. If we find that the variable appears to be statistically significant, it will figure in the regression model. Otherwise, if the variable appears to be statistically insignificant, it will not be able to enter the regression model. The following steps summarize the process for evaluating the statistical significance of variables:

1. Determination of the null hypothesis $\mathrm{HO}$ - the statement of the null hypothesis is that the variable is not significant for the regression model.

2. Determination of the alternative hypothesis $\mathrm{Hl}$ - resulting from the formulation of the null hypothesis, he claims that the observed variable is statistically significant, as it negates the original null hypothesis.

3. Determination of the significance level $\alpha$ - we determined it at the level of $10 \%$.

4. Calculation of test statistics - we find out by means of the p-value of each variable.

5. Decision to accept or reject the null hypothesis - we compare the p-value with the significance level $\alpha$. If the p-value $<\alpha$, the null hypothesis is rejected against the corresponding alternative hypothesis, which implies that the variable can be considered statistically significant. Otherwise, if the $\mathrm{p}$-value $\geq \alpha$, we do not reject the null hypothesis, which means that the observed variable is statistically insignificant.

\section{Results}

The stepwise method was used to compile a comprehensive regression model for estimating the cost of capital in the V4 countries. IBM SPSS v. Software was used for calculations. 26. Using the stepwise method, IBM SPSS created 3 regression models among all independent variables and one selected dependent variable, as shown in the table below.

Table 3: Model summary for regression model V4

\begin{tabular}{llll}
\hline $\begin{array}{l}\text { Model summary } \\
\text { Model }\end{array}$ & R square & Adjusted R square & Std. Error of the Estimate \\
\hline 1 & 0.005 & 0.005 & 0.038183556018 \\
2 & 0.006 & 0.006 & 0.038167617239 \\
3 & 0.008 & 0.008 & 0.038116958244 \\
\hline
\end{tabular}

Source: own processing 
Table 3 points to a coefficient of determination, described as $\mathrm{R}$ square, which is the proportion of the variance in the dependent variable that is predictable from the independent variables. As we can see, the first model, in which the software used only one independent capital structure to predict the dependent variable, gave this model a coefficient of determination of 0.005 . The second model, which captures up to two predictors, affects the cost of capital of the company at $0.6 \%$. The last model, which uses up to three independent variables, namely the capital structure, EBIT and the company's turnover, received an assigned R square of 0.008 and thus captures up to $0.8 \%$ of the variability of the variable cost of capital. All generated models can be considered statistically significant, as the value of std. error of the estimate is lower than the selected significance level $\alpha$ of $10 \%$. And although $\mathrm{r}$ squared is low, this model can be used for a basic orientation in estimating the cost of capital in the V4 countries.

Table 4: ANOVA for regression model V4

\begin{tabular}{|c|c|c|c|c|c|c|}
\hline \multicolumn{7}{|c|}{ ANOVA } \\
\hline \multirow{3}{*}{1} & Regression & 0.075 & 1 & 0.075 & 51.689 & $0.000^{\mathrm{b}}$ \\
\hline & Residual & 15.669 & 10,747 & 0.001 & & \\
\hline & Total & 15.744 & 10,748 & & & \\
\hline \multirow{3}{*}{2} & Regression & 0.090 & 2 & 0.045 & 30.855 & $0.000^{\mathrm{c}}$ \\
\hline & Residual & 15.654 & 10,746 & 0.001 & & \\
\hline & Total & 15.744 & 10,748 & & & \\
\hline \multirow{3}{*}{3} & Regression & 0.133 & 3 & 0.044 & 30.486 & $0.000^{\mathrm{d}}$ \\
\hline & Residual & 15.611 & 10,745 & 0.001 & & \\
\hline & Total & 15.744 & 10,748 & & & \\
\hline
\end{tabular}

Source: own processing

From the above Table 4, it is possible to assess the significance of the model in terms of the p-value (Sig.), which reaches a value of 0.000 for all 3 models. We then compare this p-value with the selected significance level $\alpha$ of $10 \%$. Since $0.000<0.10$, we reject the null hypothesis $\mathrm{H} 0$ and accept the alternative hypothesis $\mathrm{H} 1$, based on which we consider all 3 regression models to be statistically significant.

Table 5: Coefficients for the regression model of V4 countries

\begin{tabular}{|c|c|c|c|c|c|c|}
\hline \multirow{2}{*}{ Model } & & \multicolumn{2}{|c|}{ Unstandardized Coefficients } & \multirow{2}{*}{$\begin{array}{l}\text { Standardized } \\
\text { Coefficients } \\
\text { Beta } \\
\end{array}$} & & \multirow{2}{*}{ Sig. } \\
\hline & & B & Std. Error & & & \\
\hline \multirow{3}{*}{1} & (Constant) & 0.049 & 0.000 & & 133.351 & 0.000 \\
\hline & KS & $-6.016 \mathrm{E}-5$ & 0.000 & -0.069 & -7190 & 0.000 \\
\hline & (Constant) & 0.049 & 0.000 & & 131.736 & 0.000 \\
\hline \multirow[t]{3}{*}{2} & KS & $-5.996 \mathrm{E}-5$ & 0.000 & -0.069 & -7.169 & 0.000 \\
\hline & EBIT & $6.575 \mathrm{E}-8$ & 0.000 & 0.030 & 3.159 & 0.002 \\
\hline & (Constant) & 0.049 & 0.000 & & 131.595 & 0.000 \\
\hline \multirow{3}{*}{3} & KS & $-5938 \mathrm{E}-5$ & 0.000 & -0.068 & -7.108 & 0.000 \\
\hline & EBIT & $1.643 \mathrm{E}-7$ & 0.000 & 0.076 & 5.958 & 0.000 \\
\hline & OBRAT & $-1.058 \mathrm{E}-8$ & 0.000 & -0.069 & -5.439 & 0.000 \\
\hline
\end{tabular}

Source: own processing 
Before proceeding to the finalization of the regression equation, which describes the dependence between the independent variables to the selected dependent variable, it is necessary to reconsider the statistical significance of the individual variables entering the regression model. Hypotheses are tested as to whether the assessed variable is statistically significant or not. We decide whether or not to accept the null hypothesis on the basis of comparing the p-value (Sig.) of individual variables against the selected level of significance $\alpha$. The result of this comparison will be, if the p-value reaches a value lower than the significance level $\alpha$ set at the level of 10\%, the rejection of the null hypothesis and the acceptance of the alternative hypothesis $\mathrm{H} 1$, resp. in case the $\mathrm{p}$-value will have a value higher than the significance level $\alpha$, acceptance of the null hypothesis H0. From the above Table 5 we can say that the p-values of all monitored independent variables and locating constants (constant), in all models, reach a value lower than the selected level of significance $\alpha$. The result is the rejection of the null hypothesis $\mathrm{H} 0$ and the acceptance of the alternative hypothesis $\mathrm{H} 1$, on the basis of which we can claim that these variables and constants are statistically significant. Since the stepwise method offered a total of up to 3 models, we choose a model that is characterized by independent variables capital structure, EBIT and company turnover, as the coefficient of determination captures more percent variability of the dependent variable from independent variables than the other two models. As a basis for the construction of a regression equation showing the dependence of the cost of capital of the company on statistically significant independent variables in the Visegrad Four countries, we will use the information from column $\mathrm{B}$, in Table 6 , showing the values of unstandardized coefficients:

Table 6: Components of the regression equation for V4 countries

\begin{tabular}{ll}
\hline Component & Value \\
\hline $\mathrm{b}_{0}$ & 0.049 \\
$\mathrm{~b}_{1}$ & $-5.938 \mathrm{E}^{-5}$ \\
$\mathrm{~b}_{2}$ & $1.643 \mathrm{E}^{-7}$ \\
$\mathrm{~b}_{3}$ & $-1.058 \mathrm{E}^{-8}$ \\
\hline
\end{tabular}

Source: own processing

Based on the above coefficients in Table 6 we are able to create a regression equation for enterprises V4 according to equation (1), which has the following form:

$$
N K=0,049-5,938 E^{-5} \cdot K S+1,643 E^{-7} \cdot E B I T-1,058 E^{-8} \cdot O B R A T
$$

Where: $\quad N K$ is cost of capital [€],

$K S$ is capital structure [coef.],

$E B I T$ is profit before tax and interest [€],

$O B R A T$ is company turnover [€].

Non-standardized coefficients give information on how the chosen dependent, together with the independent variables, changes under ceteris paribus conditions. Taking this information into account, we can say the following:

- If the capital structure were equal to 0 , the cost of capital of the company would be $€$ 0.049, if we take into account the constant turnover of the company and EBIT.

- If the capital structure of the company is increased by 1 unit, the total cost of capital of the company will decrease by $5.938 \mathrm{E}-5 €$, again with unchanged EBIT and turnover of the company. 
- If the company's EBIT increased by just 1 unit, the total cost of capital would increase by $€ 1,643 \mathrm{E}-7$, under the conditions ceteris paribus of other variables the company's capital structure and turnover.

- Provided that the company's turnover increases by 1 unit, the cost of capital of the company will decrease, namely by $€ 1,058 \mathrm{E}-8$, assuming a constant capital structure and EBIT.

Since we have defined a formula for calculating the cost of capital in the Visegrad Four countries and the associated statistically significant independent variables, we can make the following statements based on a comparison of individual models that are specific to a given Visegrad Four country and a model covering all countries together:

- The regression model characteristic of the Republic of Hungary is most similar to the regression model for the whole $\mathrm{V} 4$, as it contains the same predictors.

- The most important variables among all regression models are capital structure and EBIT, as they occur in almost all regression equations for calculating the cost of capital.

- None of the models classifies the number of employees of the company as independent variables, whether they are models for a specific country or for a common one for V4.

- Variables company size and company sales occur in only one model, not at the same time, so after the number of employees we can consider them as the second, least significant independent variables.

\section{Discussion}

Based on a case study, in which we also monitored the statistical significance of individual variables for the successful compilation of a variation model for the calculation of capital costs, the following variables were statistically significant for each country separately using the stepwise and enter methods. Based on the following tables, we can make a number of recommendations and suggestions through which the cost of a company's capital in a particular country can either be reduced or increased. The following table 8 provides the necessary information in terms of the effects of increase or reduction of variables by 1 unit against the cost of capital of companies in the Visegrad countries, based on indicator B in Table 7.

Table 7: Significant variables by country $\mathrm{V4}$

\begin{tabular}{lll}
\hline Country & Significant variables & Value B \\
\hline \multirow{2}{*}{ Slovak Republic } & Capital Structure & $-6.455 \mathrm{E}^{-5}$ \\
& EBIT & $7.976 \mathrm{E}^{-8}$ \\
Republic of Poland & EBITDA & $3.969 \mathrm{E}^{-7}$ \\
& Company revenues & $-2.884 \mathrm{E}^{-8}$ \\
Republic of Hungary & Capital Structure & $-1.490 \mathrm{E}^{-4}$ \\
& Company turnover & $-2.207 \mathrm{E}^{-8}$ \\
& EBIT & $1.697 \mathrm{E}^{-7}$ \\
Czech Republic & Capital Structure & $-4.013 \mathrm{E}^{-5}$ \\
& EBIT & $5.261 \mathrm{E}^{-7}$ \\
Company turnover & $-1.603 \mathrm{E}^{-8}$ \\
Source: owm processing & Size of company & $8.166 \mathrm{E}^{-9}$
\end{tabular}

Source: own processing 
Capital cost quantification model in business activity planning:

The evidence of the middle Europe Countries

Authors: Zuzana Rowland, Tomas Krulicky and Olena Oliinyk

Table 8: The effect of the change in the variable on the cost of capital of enterprises in the V4 countries

\begin{tabular}{|c|c|c|c|}
\hline Country & Significant variables & Increase or decrease & Effect \\
\hline \multirow{4}{*}{ Slovak Republic } & \multirow{2}{*}{ Capital Structure } & increase & decrease of NK \\
\hline & & decrease & increase of NK \\
\hline & \multirow{2}{*}{ EBIT } & increase & increase of $\mathrm{NK}$ \\
\hline & & decrease & decrease of $\mathrm{NK}$ \\
\hline \multirow{4}{*}{ Republic of Poland } & \multirow{2}{*}{ EBITDA } & increase & increase of $\mathrm{NK}$ \\
\hline & & decrease & decrease of NK \\
\hline & \multirow{2}{*}{ Company revenues } & increase & decrease of NK \\
\hline & & decrease & increase of $\mathrm{NK}$ \\
\hline \multirow{6}{*}{ Republic of Hungary } & \multirow{2}{*}{ Capital Structure } & increase & decrease of NK \\
\hline & & decrease & increase of $\mathrm{NK}$ \\
\hline & \multirow{2}{*}{ Company turnover } & increase & decrease of $\mathrm{NK}$ \\
\hline & & decrease & increase of $\mathrm{NK}$ \\
\hline & \multirow{2}{*}{ EBIT } & increase & increase of $\mathrm{NK}$ \\
\hline & & decrease & decrease of $\mathrm{NK}$ \\
\hline \multirow{10}{*}{ Czech Republic } & \multirow{2}{*}{ Capital Structure } & increase & decrease of $\mathrm{NK}$ \\
\hline & & decrease & increase of $\mathrm{NK}$ \\
\hline & \multirow{2}{*}{ EBIT } & increase & increase of $\mathrm{NK}$ \\
\hline & & decrease & decrease of NK \\
\hline & \multirow{2}{*}{ Company turnover } & increase & decrease of $\mathrm{NK}$ \\
\hline & & decrease & increase of $\mathrm{NK}$ \\
\hline & \multirow{2}{*}{ Size of company } & increase & increase of $\mathrm{NK}$ \\
\hline & & decrease & decrease of $\mathrm{NK}$ \\
\hline & \multirow{2}{*}{ EBITDA } & increase & decrease of $\mathrm{NK}$ \\
\hline & & decrease & increase of $\mathrm{NK}$ \\
\hline
\end{tabular}

Source: own processing

As shown in Table 8, some change in the variable that is significant in the regression model for calculating the cost of capital for a particular Visegrad country results in either an increase or a decrease in the cost of capital. In the following section, we will specify how the desired change in the variable can be achieved to optimally influence the cost of capital.

\section{Capital structure}

The capital structure refers to the amount of debt and equity that the company uses to finance its operations and assets. The capital structure is characterized as the ratio of foreign capital to equity. If a company wants to increase or decrease the coefficient of capital structure, this can be done by setting the optimal capital structure, which will be reflected in the lower WACC of the company. The technical definition, which says that the ratio of foreign capital to equity is $2 / 3: 1 / 3$, is not widely used in common practice, as it is only a strategic-philosophical view of the optimal capital structure, but this recommendation does not need to be completely rejected.

1. By issuing bonds to the financial market, while repurchasing its own equity - the company "borrows" money by issuing bonds and then uses all the capital raised to repurchase shares from its shareholders, this will have the effect of debt and reduce the amount of equity in the balance sheet.

2. By issuing bonds to the financial market, paying a large dividend to its shareholders as in the first case, the company issues bonds in order to obtain additional funds, which 
it then uses to pay a special dividend, reducing the value of equity by redistributed amount, increase the value of foreign sources again.

3. By issuing its shares, while repaying its foreign resources - in this approach, the company moves in the opposite direction, wants to use the capital obtained from the issuance of shares into circulation to repay part of its debt, thereby reducing the value of its debt.

Each of the above three methods can be effective in terms of the optimal capital structure of the company. However, the pros and cons of each way of financing one's business must be carefully assessed.

\section{EBIT}

There are several practical steps we can take to increase or decrease EBIT, depending on what the target business wants to achieve. Examples of such steps include the following:

1. Increase or decrease in sales revenues - this can be achieved by increasing the sales price, in case we want to increase revenues, otherwise such a price must be reduced,

2. Creation of new demand - new demand, which is used correctly, is able to produce higher sales revenues, which also results in higher EBIT, this step can be achieved, for example, through excellent marketing.

3. Discount management - especially companies focused on the sale of their products should be aware of the real value of their products and be able to effectively determine the optimal amount of discount.

\section{EBITDA}

Like EBIT, EBITDA, as a profitable indicator, can also be influenced in terms of revenue volume, new demand generation and discount management, but there are other steps the company can take to adjust this indicator. These include, for example, effective inventory management, as the so-called "Dead money" that is in excess inventory does not produce any income, is subject to amortization and depreciation, and negatively affects EBITDA.

\section{Sales and turnover of the company}

The company's sales, as well as the company's turnover, can be increased in several ways, we offer several of them. In the event that we would like to negatively affect sales, the following steps should be negated:

1. Unambiguous definition of the customer - orientation to its target segment.

2. Building a competitive advantage in the market - based on this advantage, the company's sales can increase positively,

3. Choosing the right price for your products.

\section{Size of company}

By the size of the company we mean its total assets. It can be increased either through equity or debt, based on the findings we presented in the section on capital structure.

\section{References}

Amihud, Y., and Mendelson, M. (1986). Asset pricing and the bid-ask spread. Journal of Financial Economics, 15(8), pp. 223-249.

Bae, K.H., El Ghoul, S., Geudhami, O., Kwok, C.C.Y. and Zheng, Y. (2019). Does corporate social responsibility reduce the costs of high leverage? Evidence from capital structure and product market interactions. Journal of Banking \& Finance, 100, pp. 135-150. 
Bernardi, M., Cerqueti, R. and Palestini, A. (2019). Allocation of risk capital in cost cooperative game included by a modified expected shortfall. Journal of the Operational Research Society, early access.

Botosan, C. A. (1997). Disclosure level and the cost of equity capital. The Accounting Review, 72(3), pp. 323-349.

Botosan, C.A. and Plumlee, M.A. (2002). A re-examination of disclosure level and the expected cost of equity capital. Journal of Accounting Research, 40(1), pp. 21-40.

Botosan, C.A. and Plumlee, M.A. (2005). Assessing alternative proxies for the expected risk premium. Accounting Review, 80(1), pp. 21-53.

Brealey, R., Cooper, I.A. and Habib, M.A. (2020). Cost of capital and valuation in the public and private sectors: Tax, risk and debt capacity. Journal of Business Finance \& Accounting, 47(1-2), pp. 163-187.

Callen, J. and Lyle, M.R. (2019). The term structure of implied costs of equity capital. Review of Accounting Studies, 25(1), pp. 342-404.

Chordia, T., Hu, J., Subrahmanyam, A. and Tong, Q. (2019). Order flow volatility and equity costs of capital. Management Science, 65(4), pp. 1520-1551.

Clarkson, P., Guedes, J. and Thompson, R. (1996). On the diversification, observability and measurement of estimation risk. Journal of Financial and Quantitative Analysis, 31(1), pp. 69-84.

Dhaliwal, D.S., Li, O.Z., Tsang, A. and Yang, Y. G. (2011). Voluntary nonfinancial disclosure and the cost of equity capital: The initiation of corporate social responsibility reporting. Accounting Review, 86(1), pp. 59100.

Easley, D. and O'Hara, M. (2004). Information and the cost of capital. The Journal of Finance, 59(10), pp. 15531583.

Fama, E. F. and French, K. R. (1997). Industry Costs of Equity. Journal of Financial Economics, 43(2), pp. 15393.

Egli, F., Steffen, B. and Schmidt, T.S. (2019). Bias in energy system models with uniform cost of capital assumption. Nature Communications, 10, pp. 4588.

Francis, S. J. R., Khurana, I. K. and Pereira, R. (2005). Disclosure incentives and effects on cost of capital around the world. The Accounting Review, 80(4), pp. 1125-1162.

Francis, J., Lafond, R., Ollson, P. and Schipper, K. (2004). The market pricing of accruals quality. Journal of Accounting and Economics, 39(2), pp. 295-327.

Gebhardt, W.R., Lee, C.M.C. and Swaminathan, B. (2001). Toward an implied cost of capital. Journal of Accounting Research, 39(1), pp. 135-176.

Gietzamn, M. B. and Ireland, J. (2005). Cost of capital, strategic disclosures and accounting choice. Journal of Business Finance \& Accounting, 32(3), pp. 599-634.

Glosten, L. R. and Milgrom, P.R. (1985). Bid, ask and transaction prices in specialist market with heterogeneously informed traders. Journal of Financial Economics, 14(3), pp. 71-100.

Guay, W., Kothari, S.P. and Shu, S. (2011). Properties of implied cost of capital using analysts' forecasts. Australian Journal of Management, 36(2), pp. 34-60.

Kent, R. A. and Bu, D. (2020). The importance of cash flow disclosure and cost of capital. Accounting and Finance, 80(4), pp. 877-908.

Kothari, S. P., Li, X. and Short, J. E. (2009). The effect of disclosures by management, analysts and financial press on the cost of capital, return volatility, and analyst forecasts: a study using content analysis. The Accounting Review, 85(5), pp. 1639-1670.

Lambert, R., Leuz, C. and Verrecchia, R. E. (2007). Accounting information, disclosure, and the cost of capital. Journal of Accounting Research, 39(1), pp. 135-176.

Lee, C., Ng, D. and Swaminathan, B. (2009). Testing international asset pricing models using implied costs of capital. Journal of Financial and Quantitative Analysis, 44(2), pp. 307-335.

Leuz, C. and Verrecchuia, R. E. (2004). Firms' capital allocation choices, information quality, and the cost of capital. Working paper. Pennsylvania: University of Pennsylvania - Accounting Department.

Mihov, A. and Naranjo A. (2019). Corporate internationalization, subsidiary locations, and the cost of equity capital. Journal on International Business Studies, 50(9), pp. 1544-1565.

Valaskova, K., Lazaroiu, G., Olah, J., Siekelova, A. and Lancova, B. (2019). How capital structure affects business valuation: A case study of Slovakia. Central European Business Review, 8(3), pp. 1-17.

Vitolla, F., Salvi, A., Raimo, N., Petruzzella, F. and Rubino, M. (2019). The impact of the cost of equity capital in the effects of integrated reporting quality. Business Strategy and the Environment, 29(2), pp. 519-529.

Wang, Z. M., Ettinger, M., Xie, Y.Y. and Xu, L. (2020). The cost of capital: U.S.-based multinational corporations versus U.S. domestic corporations. Global Finance Journal, 44(5), pp. 43. 